\title{
The Potential of Low-Carbon Development of the Polish Economy
}

\author{
Maria DZIKUĆ ${ }^{1}$, Szymon SZUFA ${ }^{2}$, Janusz ADAMCZYKํ, Maciej DZIKUĆ ${ }^{*}$ and \\ Piotr KUŁYK ${ }^{1}$ \\ 1 University of Zielona Góra, Zielona Góra, Poland; ma.dzikuc@wez.uz.zgora.pl; m.dzikuc@wez.uz.zgora.pl \\ j.adamczyk@wez.uz.zgora.pl; p.kulyk@wez.uz.zgora.pl \\ 2 Lodz University of Technology, Łódź, Poland; szymon.szufa@p.lodz.pl \\ * Correspondence: m.dzikuc@wez.uz.zgora.pl
}

\begin{abstract}
Poland is currently a dynamically developing country belonging to the European Union. However, the economic development does not go hand in hand with improving the quality of the environment. The air quality in Poland is one of the worst in the entire European Union. Although industry generally meets current ecological standards (especially large enterprises), the air quality is negatively affected by heating buildings, road transport, agriculture and small enterprises. It should be emphasized that heating single-family houses using old, energy-inefficient boilers, in which low-quality fuel is burned, has the greatest impact on poor air quality in Poland. Despite actions taken to reduce emission in Poland, concentrations of harmful substances in the air are still exceeded. Poor air quality contributes to the additional costs associated with the absence of sick workers in the workplace. The aim of the article is to present the conditions related to the low-carbon development in Poland. The article indicates the potential of the LCA technique, which can effectively support activities for low-carbon development.
\end{abstract}

Keywords: economy; low-carbon development; energy; Poland

JEL Classification: O11; Q53; Q56

\section{Introduction}

The economic development that has taken place in Poland over the last three decades has translated into the quality of infrastructure and the standard of living of Poles. However, the economic development has too little impact on reducing the amount of pollution that gets into the air (Truong et al., 2019). It is important that in Poland the problem is not only the excessive amount of $\mathrm{CO}_{2}$ emitted into the air, but also other substances that directly affect human health and the environment (Yang and Liu, 2018). The excessive $\mathrm{CO}_{2}$ emission has a negative impact on the environment, but from the social point of view it is not felt in the short term (Dzikuć et al., 2020). Changes caused by the excessive $\mathrm{CO}_{2}$ emission are spread over time and it is more difficult to attribute a specific number of illnesses or premature deaths to people (Wattanakuljarus, 2019; Bedir \& Yilmaz, 2016; Stewart et al., 2019). From the residents' point of view, harmful substances such as suspended particulates or benzo(a)pyrene - B(a)P, which directly affect human health, may seem more important (Balmes, 2019). Pollutants contained in the air, such as particulate matter PM2.5 and PM10 are not only the cause of malaise, but also contribute to the occurrence of serious respiratory and cardiovascular diseases. Furthermore, air pollution can affect the formation and strengthening of mental disorders. Various air pollutants, in particular particulate matter and nitrogen oxides, may be associated with poor 
mental health. Long exposure to PM2.5 may increase the risk of depressive symptoms (Sass et al., 2017). However, increased levels of nitrogen dioxide can lead to worsening of existing depressive conditions (Buoli et al., 2018). The aim of the article is to present the conditions related to the low-carbon development in Poland. The article indicates the potential of the LCA technique, which can effectively support activities for low-carbon development.

\section{The Sources of Air Pollution}

Many factors affect the air quality. The most important of them include: the amount and type of raw materials used for energy production, the share of ecological installations, including those based on renewable sources (Figure 1). Poland uses a large amount of solid fuels, which often contribute to air pollution during combustion (Ciupek et al., 2019; Zaporozhets and Khaidurov, 2020). In 2016, almost 20\% less solid fuels were burned in Poland than in Germany, where more than twice as many people live as in Poland (Cutz et al., 2019). In addition, Germany is the fourth economy in the world that produces much more products than Poland. In Poland, gas fuels are used to a much lesser extent than in other EU countries of similar size, whose combustion pollutes the environment to a lesser extent (Bitat, 2018).

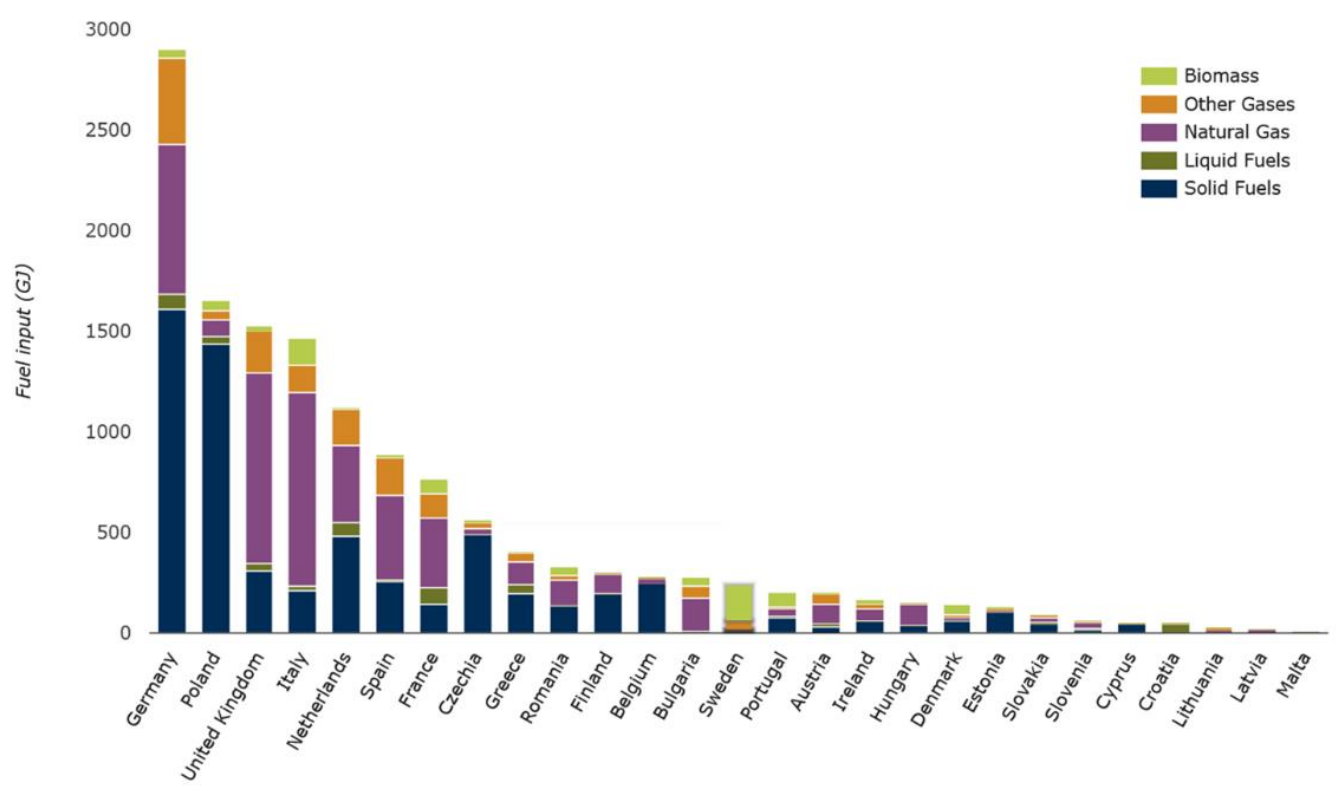

Figure 1. Fuel inputs used in 2017 by country and fuel type. European Environment Agency (2019)

An important factor affecting the air quality is also the technology used for generating energy. This is especially important when burning fossil fuels, because old technologies are characterized by much lower energy efficiency and contribute to the emission of much more harmful gases and dust into the air. Another factor is the use of filters that allow the retention of the vast majority of harmful substances that do not get into the air. However, it should be emphasized that mainly large industrial plants and power plants are equipped with this type of installations. Smaller installations, such as home boiler rooms, are not equipped with any filters, which is particularly noticeable during the heating season (Dzikuć et al., 2017). An additional problem is the fact that a large proportion of single-family houses in Poland do not have adequate thermal insulation, which increases the consumption of thermal 
energy, which is often produced using energy-inefficient boilers. It is estimated that approximately 3.5 million flats, mainly single-family buildings, require thermal modernization in Poland (Piwowar, 2019; Junga et al., 2020).

The last three decades have been a period in which excessive emission of harmful substances has been largely reduced, the source of which was industry and the energy sector (Leisen et al., 2019; Garba et al., 2020). Although the $\mathrm{CO}_{2}$ emission has still not been reduced. However, this will not be done in the coming years because the energy sector in Poland is based on coal and it will be possible to switch it to other sources only in the long run (Szufa et al., 2020b; Romanowska-Duda et al., 2020; Piwowar \& Dzikuć, 2019). Currently, industry in Poland meets ecological standards (especially large enterprises). However, the air quality is greatly affected by heating buildings, road transport (Dzikuć et al., 2017; Laskowski et al., 2019; Bielaczyc \& Woodburn, 2019), agriculture and small businesses. It should be emphasized that heating single-family houses using old, energy-inefficient boilers, in which low-quality fuel is burned, has the greatest impact on poor air quality in Poland.

According to the report of the European Environment Agency (EEA) entitled "Air quality in Europe - 2018", Poland is one of the countries with the most polluted air in the EU. According to EEA, there are 19 out of 20 cities most polluted by B(a)P in Poland. EEA analysed data on air pollution in 2016 in over 2.5 thousand cities from 41 European countries (including all EU countries). The concentration of suspended dusts (PM2.5 and PM10), carcinogenic $\mathrm{B}(\mathrm{a}) \mathrm{P}$, nitrogen oxides as well as sulfur and ozone compounds were tested. Unfortunately, Polish cities are among the most polluted in the EU. According to the guidelines, WHO indicates that the average annual $\mathrm{B}(\mathrm{a}) \mathrm{P}$ concentration should not exceed $1 \mathrm{ng} / \mathrm{m}^{3}$. However, in many cities in Poland this level is exceeded many times during the heating season, e.g. in Nowa Ruda, the $\mathrm{B}(\mathrm{a}) \mathrm{P}$ level is almost $18 \mathrm{ng} / \mathrm{m}^{3}$. Unfortunately, Nowa Ruda is not the only city in Poland where the level of $\mathrm{B}(\mathrm{a}) \mathrm{P}$ is exceeded several times. Moreover, the excessive concentration of particulate matter in the air, PM2.5 and PM10, means that Polish cities are also among the infamous leaders in the EU's most polluted.

It should be emphasized that in recent years in Poland the level of $\mathrm{B}(\mathrm{a}) \mathrm{P}$ emission has been at a similar level (Table 1). Poland is not the only country in the EU where the $\mathrm{B}(\mathrm{a}) \mathrm{P}$ concentration in the air has not been reduced in recent years (Czyżewski et al., 2020). However, in Poland, B (a) P emissions are the highest in the entire EU. The problem of excessive concentrations of $\mathrm{B}(\mathrm{a}) \mathrm{P}$ in the air does not only apply to highly industrialized and densely populated areas. Also, less industrialized regions (Kopczyński et al., 2017), where the population density is lower than in other parts of the country, may be excessively contaminated by B(a)P.

Analyzing the distribution of the average annual normative value of the concentration of B(a)P contained in PM10 in Poland in 2017, it should be noted that the problem concerns almost every major town in the country. The results of $\mathrm{B}(\mathrm{a}) \mathrm{P}$ concentration in the air obtained in 2017 indicate a significant exceeding of the target level specified for this substance in all zones where measurements were carried out (Dzikuć, 2013). Due to significant exceeding of permissible concentrations of $\mathrm{B}(\mathrm{a}) \mathrm{P}$ in the air in Poland, almost all zones were included in class $C$, which creates the obligation to develop air protection programs. Only 3 zones out of 
Table 1. Member State contributions to EU emissions of B(a)P. European Environment Agency (2019)

\begin{tabular}{|c|c|c|c|c|c|c|c|c|c|c|c|c|c|c|c|c|c|}
\hline \multirow[t]{2}{*}{ Member State } & \multicolumn{13}{|c|}{ Benzo(a)pyrene (Mg) } & \multicolumn{2}{|c|}{ Change $(\%)$} & \multicolumn{2}{|c|}{$\begin{array}{l}\text { Share in } \\
\text { EU-28 (\%) }\end{array}$} \\
\hline & 1990 & 1995 & 2000 & 2005 & 2010 & 2011 & 2012 & 2013 & 2014 & 2015 & 2016 & 2017 & 2018 & $\begin{array}{l}1990- \\
2018\end{array}$ & $\begin{array}{l}2017- \\
2018\end{array}$ & 1990 & 2018 \\
\hline Austria & & & & & & & & & & & & & & -83 & -0.9 & 2.3 & 0.9 \\
\hline Belgium & 15 & 12 & 9.6 & 7.7 & 5.3 & 4.7 & 4.0 & 3.9 & 2.6 & 2.7 & 2.8 & 2.6 & 2.6 & -83 & -0.9 & 2.3 & 0.9 \\
\hline Bulgaria & 83 & 77 & 1,900 & 3,429 & 20 & 31 & 39 & 43 & 100 & 106 & 101 & 71 & 4.9 & -94 & -93.0 & 12.2 & 1.8 \\
\hline Croatia & 7.0 & 5.7 & 5.1 & 6.3 & 6.0 & 5.7 & 5.6 & 5.5 & 4.8 & 5.4 & 5.2 & 5.0 & 4.8 & -32 & -3.7 & 1.0 & 1.7 \\
\hline Cyprus & 2.4 & 1.9 & 1.1 & 0.7 & 0.2 & 0.2 & 0.2 & 0.1 & 0.1 & 0.2 & 0.1 & 0.1 & 0.1 & -95 & 10.1 & 0.3 & 0.0 \\
\hline Czechia & 91 & 60 & 17 & 14 & 17 & 17 & 17 & 17 & 16 & 16 & 16 & 16 & 16 & -83 & -2.6 & 13.5 & 5.7 \\
\hline Denmark & 3.5 & 3.6 & 3.0 & 3.1 & 2.5 & 2.2 & 2.2 & 2.2 & 2.0 & 2.2 & 2.3 & 2.3 & 2.2 & -36 & -1.1 & 0.5 & 0.8 \\
\hline Estonia & 2.4 & 2.8 & 2.4 & 2.1 & 2.4 & 2.0 & 2.0 & 2.1 & 2.0 & 2.0 & 2.0 & 2.2 & 2.2 & -5 & 0.1 & 0.4 & 0.8 \\
\hline Finland & 0.2 & 0.2 & 0.2 & 0.2 & 0.2 & 0.2 & 0.2 & 0.2 & 0.2 & 0.2 & 0.2 & 0.2 & 0.2 & 21 & -0.4 & 0.0 & 0.1 \\
\hline France & 13 & 13 & 9.8 & 7.3 & 6.0 & 5.1 & 5.5 & 5.8 & 5.0 & 5.0 & 5.1 & 5.0 & 4.7 & -63 & -4.7 & 1.9 & 1.7 \\
\hline Germany & 139 & 48 & 31 & 23 & 35 & 31 & 35 & 37 & 29 & 30 & 28 & 29 & 28 & -80 & -2.9 & 20.6 & 10.3 \\
\hline Greece & 37 & 40 & 39 & 39 & 35 & 36 & 36 & 36 & 32 & 31 & 30 & 31 & 31 & -16 & 0.9 & 5.4 & 11.3 \\
\hline Hungary & 26 & 9.9 & 8.5 & 7.8 & 9.6 & 11 & 12 & 12 & 9.4 & 9.9 & 10 & 9.8 & 8.0 & -69 & -18.4 & 3.9 & 2.9 \\
\hline Ireland & 14 & 8.6 & 6.1 & 5.6 & 5.2 & 4.9 & 4.7 & 5.1 & 4.4 & 4.3 & 4.0 & 3.6 & 3.7 & -73 & 3.9 & 2.0 & 1.4 \\
\hline Italy & 10 & 11 & 11 & 12 & 21 & 14 & 19 & 19 & 17 & 18 & 17 & 19 & 17 & 67 & -10.2 & 1.5 & 6.1 \\
\hline Latvia & 6.3 & 6.0 & 6.1 & 4.8 & 3.6 & 3.7 & 3.6 & 3.2 & 3.1 & 2.6 & 2.5 & 2.8 & 2.9 & -54 & 3.8 & 0.9 & 1.1 \\
\hline Lithuania & 6.4 & 3.1 & 3.2 & 3.6 & 3.8 & 3.8 & 3.8 & 3.7 & 3.4 & 3.1 & 3.2 & 3.2 & 3.2 & -51 & -0.9 & 0.9 & 1.2 \\
\hline Luxembourg & 1.2 & 0.6 & 0.2 & 0.2 & 0.2 & 0.1 & 0.1 & 0.2 & 0.2 & 0.1 & 0.2 & 0.2 & 0.2 & -85 & 10.2 & 0.2 & 0.1 \\
\hline Malta & 0.2 & 0.1 & 0.1 & 0.1 & 0.1 & 0.1 & 0.1 & 0.1 & 0.1 & 0.1 & 0.1 & 0.1 & 0.0 & -96 & -93.8 & 0.0 & 0.0 \\
\hline Netherlands & 4.9 & 2.9 & 1.8 & 1.9 & 1.8 & 1.8 & 1.7 & 1.7 & 1.7 & 1.7 & 1.6 & 1.6 & 1.6 & -68 & -2.2 & 0.7 & 0.6 \\
\hline Poland & 101 & 123 & 73 & 93 & 101 & 87 & 87 & 82 & 72 & 72 & 75 & 75 & 73 & -27 & -2.1 & 14.9 & 26.6 \\
\hline Portugal & 8 & 7 & 6 & 5 & 4 & 4 & 4 & 4 & 4 & 4 & 4 & 4 & 5 & -39 & 9.1 & 1.1 & 1.7 \\
\hline Romania & 17 & 10 & 16 & 18 & 20 & 18 & 19 & 18 & 18 & 18 & 18 & 17 & 17 & 5 & -0.2 & 2.5 & 6.4 \\
\hline Slovakia & 15 & 8.3 & 7.7 & 9.4 & 8.8 & 8.4 & 8.7 & 8.1 & 6.6 & 7.1 & 7.3 & 7.1 & 6.2 & -59 & -12.8 & 2.2 & 2.3 \\
\hline Slovenia & 2.8 & 2.2 & 2.0 & 2.4 & 2.5 & 2.5 & 2.4 & 2.5 & 2.0 & 2.2 & 2.2 & 2.1 & 1.9 & -31 & -8.9 & 0.4 & 0.7 \\
\hline Spain & 30 & 25 & 27 & 26 & 30 & 30 & 26 & 31 & 26 & 29 & 32 & 28 & 28 & -8 & -1.0 & 4.5 & 10.1 \\
\hline Sweden & 6.2 & 6.3 & 4.9 & 5.3 & 3.4 & 3.3 & 3.1 & 3.0 & 2.8 & 2.7 & 2.7 & 2.6 & 2.3 & -64 & -13.6 & 0.9 & 0.8 \\
\hline United Kingdom & 35 & 23 & 6.9 & 6.0 & 7.8 & 6.8 & 7.8 & 8.2 & 7.2 & 7.8 & 7.9 & 7.7 & 8.1 & -77 & 4.7 & 5.1 & 2.9 \\
\hline EU-28 (a) & 676 & 511 & 2,199 & 3,735 & 351 & 334 & 350 & 354 & 374 & 382 & 381 & 348 & 275 & -59 & -21.1 & 100 & 100 \\
\hline EU-28 (b) & 676 & 511 & 2,199 & 3,735 & 351 & 334 & 350 & 354 & 374 & 382 & 381 & 348 & 275 & & & & \\
\hline
\end{tabular}

(a) Sum of national totals, as reported by EU Member States and the United Kingdom. ( ${ }^{\text {b }}$ ) Sum of sectors. 


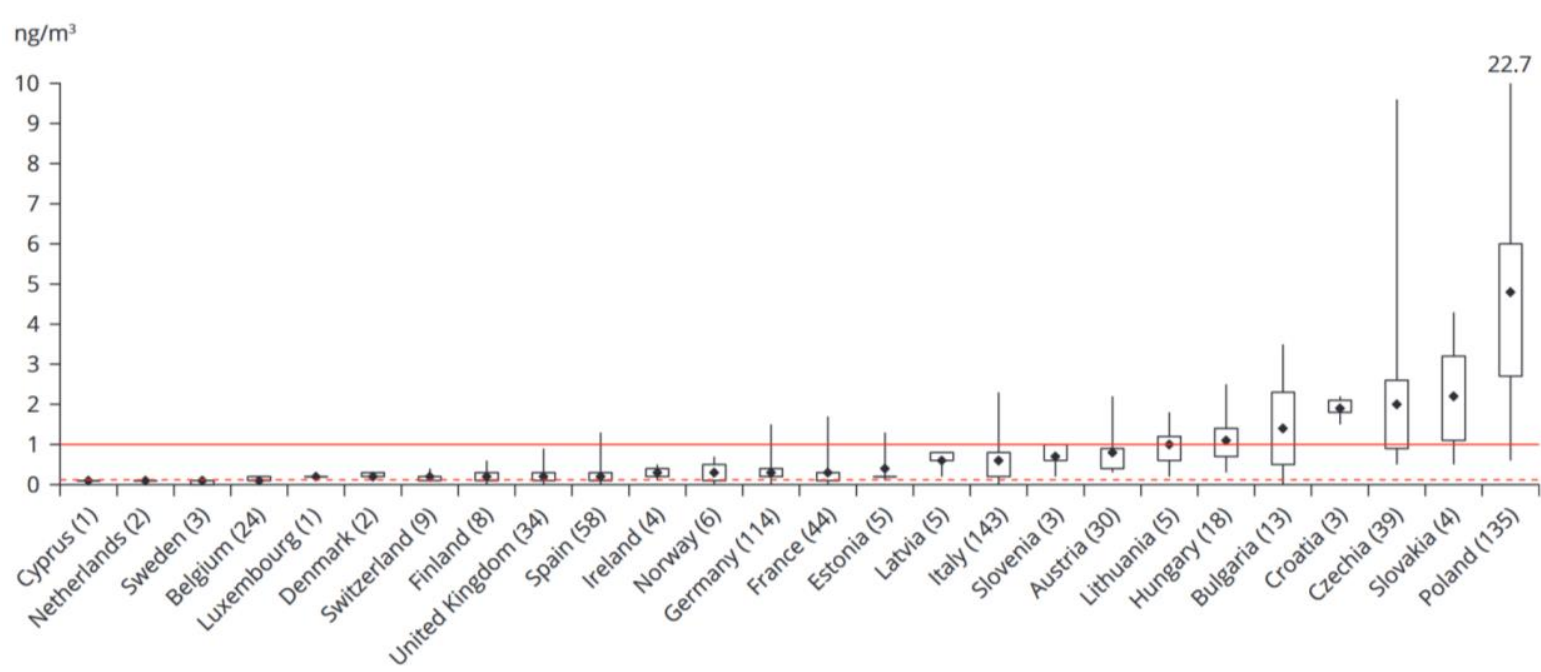

Figure 2. B(a)P concentrations in 2017 and number of stations considered for each country. World Health Organization (2020)

46 examined, i.e. the city of Koszalin, the city of Olsztyn and the Tri-City Agglomeration were qualified to zone A, which means that only these 3 locations are characterized by no exceedances of $\mathrm{B}(\mathrm{a}) \mathrm{P}$ concentrations in the air (Inspectorate of Environmental Protection 2018). The scale of excessive concentrations of $\mathrm{B}(\mathrm{a}) \mathrm{P}$ in the air that occur in Poland is clearly illustrated in Figure 2.

Figure 2. is based on the annual mean concentration values. For each country, the number of stations considered (in brackets), and the lowest, highest and average values (in $\mathrm{ng} / \mathrm{m} 3$ ) recorded at its stations are given. The rectangles mark the 25th and 75th percentiles. At $25 \%$ of the stations, levels are below the lower percentile; at $25 \%$ of the stations, concentrations are above the upper percentile. The upper horizontal line marks the concentration of $1.0 \mathrm{ng} / \mathrm{m} 3$. The lower horizontal line marks the estimated air quality RL. The graph should be read in relation to Map 6.1, as a country's situation depends on the number of stations considered. The highest value for Poland, $22.7 \mathrm{ng} / \mathrm{m} 3$, is out of the graph for representation purposes.

When analysing air pollution in Poland, the $\mathrm{CO}_{2}$ emission should not be neglected, although from the point of view of residents, excessive $\mathrm{CO}_{2}$ may seem like a smaller problem, because this greenhouse gas does not directly affect the quality of the environment and human health in a short period of time. In the long run, however, the excessive $\mathrm{CO}_{2}$ emission can be harmful to humans due to the deterioration of the quality of life through global warming, which in turn can cause more frequent rapid atmospheric phenomena (Dai et al., 2015). However, the effects of global warming can be observed more and more often not only in the world, but also in Poland. These include violent atmospheric phenomena and melting of glaciers (Szufa et al., 2020a).

According to Eurostat estimates, the level of $\mathrm{CO}_{2}$ emission from energy consumption in 2018 fell by $2.5 \%$ in the EU compared to 2017. $\mathrm{CO}_{2}$ emissions are an important factor affecting global warming and account for around $80 \%$ of all EU greenhouse gas emissions. It should be emphasized that, according to Eurostat estimates, while $\mathrm{CO}_{2}$ emissions fall across the EU, in Poland it has increased. The increase in the share of $\mathrm{CO}_{2}$ emissions in Poland results from economic growth and the fact that the energy sector is based in $80 \%$ on coal, whose combustion is the main reason for the increase in $\mathrm{CO}_{2}$ emissions (Woźniak \& Pactwa, 2018). 
Poland will be forced to reduce $\mathrm{CO}_{2}$ emissions in the future not only because of the EU policy, but also for economic reasons, as prices of $\mathrm{CO}_{2}$ emission allowances have increased several times over the past several months. The Polish economy, which is dominated by coal, will be less competitive compared to countries whose energy systems are based more on renewable energy or nuclear energy. High prices of $\mathrm{CO}_{2}$ emission allowances in the long run will force greater activity in Poland in the implementation of low-carbon solutions that have not been economically justified until now (Costantini et al., 2019).

\section{The Impact of Air Pollution on Life Quality}

Excessive amounts of harmful substances in the air affect many aspects of human life and the environment. Regardless of whether the analysis will include substances that are felt by people in a short period of time, e.g. B(a)P. Also important are gases that affect the environment and, consequently, people's quality of life, such as $\mathrm{CO}_{2}$, whose impact is spread over time, but changes caused by rising average temperatures on the earth are noticeable and can be very severe for the inhabitants of most regions of the world. Repeated heat waves during the summer, which are especially dangerous for older people, can increasingly lead to tens of thousands of deaths.

Despite actions taken to reduce emission in Poland, concentrations of harmful substances in the air are still often exceeded and the air quality in Poland is one of the worst in the entire EU. Poor air quality not only contributes to the deterioration of living conditions of residents, but also affects the need to incur additional costs associated with the absence of sick employees in the workplace. Moreover, it is estimated that about 47.5 thousand people die every year in Poland due to poor air quality (Table 2) (World Health Organization, 2020). Which significantly exceeds the EU average. This result is mainly affected by air pollution with PM2.5 suspended dust, which is characterized by almost the highest annual average. Only Bulgaria is more polluted with 2.5 dust. Poor air quality, caused by excessive emission of particulate matter, is not a new problem in Poland and has been recorded in principle since the beginning of measurements of airborne concentrations of this harmful substance. In contrast, Poland has slightly lower $\mathrm{NO}_{2}$ pollution than the EU average and close to the average ozone concentration.

Extreme weather events can, as a consequence, lead to the loss of health or lives of many people and paralyze the conduct of business. The resources needed to rebuild damaged infrastructure are often calculated in millions of euros. Much of the damage is conditioned by extreme weather phenomena. In addition, higher air temperatures affect the length of the growing season, not only in Poland and the EU, but in many places around the world. The flowering and harvesting season for cereals is accelerating, which may bring some positive changes in regions that have hitherto had a cooler climate, e.g. northern Europe (Kibria et al., 2018). However, a more serious problem is the increase in temperature, which may lead to a decrease in the amount of rainfall, thereby reducing crop yields in central and southern Europe, including Poland.

Another effect of excessive human interference in the environment through excessive emission of gases and dust into the air is the melting of glaciers and rising sea and ocean 
levels, which will flood the areas previously inhabited by people and used by them for the purposes of agriculture or running business activities. The oceans' temperature rise accelerates the metabolism of organisms and increases their oxygen consumption. This reduces the oxygen concentration in the water and, as a consequence, can lead to a situation where some of the marine waters begin to die.

Table 2. Premature deaths attributable to $\mathrm{PM} 2.5$ and $\mathrm{NO}_{2}$ exposure in the EU-28, 2015. European Environment Agency (2019)

\begin{tabular}{|c|c|c|c|c|c|}
\hline \multirow[b]{2}{*}{ Country } & \multirow{2}{*}{$\begin{array}{c}\text { Population } \\
(1,000)\end{array}$} & \multicolumn{2}{|c|}{ PM2.5 } & \multicolumn{2}{|c|}{$\mathrm{NO}_{2}$} \\
\hline & & $\begin{array}{l}\text { Annual mean } \\
\text { (a) }\end{array}$ & $\begin{array}{l}\text { Premature } \\
\text { deaths }\left({ }^{b}\right)\end{array}$ & $\begin{array}{c}\text { Annual mean } \\
\text { (a) }\end{array}$ & $\begin{array}{l}\text { Premature } \\
\text { deaths }\left(^{b}\right)\end{array}$ \\
\hline Austria & 8,576 & 13.3 & 5,900 & 19.8 & 1,200 \\
\hline Belgium & 11,237 & 13.0 & 7,400 & 20.9 & 1,500 \\
\hline Bulgaria & 7,202 & 24.1 & 14,200 & 16.1 & 640 \\
\hline Croatia & 4,225 & 17.4 & 4,500 & 17.3 & 430 \\
\hline Cyprus & 1,173 & 16.9 & 750 & 14.1 & 30 \\
\hline Czechia & 10,538 & 17.0 & 10,100 & 16.6 & 490 \\
\hline Denmark & 5,660 & 9.7 & 2,800 & 10.5 & 80 \\
\hline Estonia & 1,315 & 6.7 & 560 & 8.2 & $<5$ \\
\hline Finland & 5,472 & 5.3 & 1,500 & 8.8 & 40 \\
\hline France & 66,488 & 11.9 & 35,800 & 17.9 & 9,700 \\
\hline Germany & 81,198 & 12.3 & 62,300 & 20.0 & 13,100 \\
\hline Greece & 10,858 & 19.1 & 12,000 & 18.1 & 2,300 \\
\hline Hungary & 9,856 & 18.9 & 12,800 & 18.0 & 1,300 \\
\hline Ireland & 4,629 & 6.5 & 1,100 & 7.6 & 30 \\
\hline Italy & 60,796 & 18.5 & 60,600 & 24.9 & 20,500 \\
\hline Latvia & 1,986 & 10.6 & 1,600 & 12.1 & 130 \\
\hline Lithuania & 2,921 & 11.7 & 2,600 & 12.2 & 70 \\
\hline Luxembourg & 563 & 12.0 & 240 & 19.9 & 50 \\
\hline Malta & 429 & 12.8 & 240 & 16.5 & 20 \\
\hline Netherlands & 16,901 & 12.3 & 9,800 & 20.5 & 1,900 \\
\hline Poland & 38,006 & 21.6 & 44,500 & 15.6 & 1,700 \\
\hline Portugal & 9,870 & 9.8 & 5,500 & 15.7 & 890 \\
\hline Romania & 19,871 & 18.1 & 25,400 & 14.9 & 1,300 \\
\hline Slovakia & 5,421 & 19.1 & 5,200 & 16.9 & 240 \\
\hline Slovenia & 2,063 & 17.4 & 1,800 & 16.7 & 160 \\
\hline Spain & 44,154 & 12.7 & 27,900 & 21.2 & 8,900 \\
\hline Sweden & 9,747 & 5.9 & 3,000 & 10.8 & 110 \\
\hline United Kingdom & 64,875 & 9.4 & 31,300 & 19.7 & 9,600 \\
\hline EU-28 & 506,030 & 13.9 & 391,000 & 18.9 & 76,000 \\
\hline
\end{tabular}




\section{Potential for Low-Carbon Development Activities}

The implementation and maintenance of sustainable low-carbon development in Poland will require the involvement of significant financial resources. Although low-carbon solutions are considered expensive and they are often perceived as an additional burden for the economy, these expenses should be combined with the costs of developing coal energy, the costs of which will grow in the future, including due to the rising costs of coal extraction, which must be extracted from less accessible places, and the rising costs associated with the $\mathrm{CO}_{2}$ emission charges. A completely different problem is the fact that this raw material is running out. EU member states, including Poland, allocate significant funds to low-carbon development. However, in some countries $\mathrm{CO}_{2}$ emissions are rising and emissions of harmful substances such as particulate matter remain at a similar level.

National governments are already aware that in the future it will be necessary to completely abandon fossil fuels. Of course, this raises many problems, such as the loss of jobs for people employed in the energy sector. It should be emphasized that people will need energy and that, along with reducing energy production by burning coal, it will be necessary to develop renewable energy sources, in which employees will also be needed (Leseure et al., 2019). Moving to an economy that will be more based on renewable energy requires time and resources, especially in a country like Poland, whose energy sector is $80 \%$ coal-based. It should be emphasized that, in line with the Europe 2020 strategy, the EU allocates in its 20142020 budget almost 1 trillion euros for sustainable growth, jobs and competitiveness. At least one-fifth of the EU budget for 2014-2020 will be allocated to the transition to a low-carbon European economy. Giving up the use of fossil fuels for renewable energy is very difficult and will require a change in the entire energy system (Mikielewicz et al., 2019).

Limiting the burning of fossil fuels is currently one of the most important conditions for reducing greenhouse gas emissions to the atmosphere. Solid fuels are among the most important elements of the global energy system and meet the demand for electricity and heat (Tucki et al., 2019b; Szatyłowicz \& Skoczko, 2019).

The implementation of low-carbon development in Poland is conditioned by many factors. The economic factor is particularly important. The excessive amount of gas and dust emitted into the air is due to many reasons. One of them is long-term neglect, which is associated with the lack of regulations limiting the emission of harmful substances into the air from home boiler rooms. It is only in recent years that solutions have begun to be implemented whose effects are not yet visible. While industrial emissions have been significantly reduced, no solutions have been introduced that would significantly reduce a diffuse emission. The problem is possible to solve because most EU countries with a similar climate are doing much better than Poland. In Poland, there have been no legal solutions explicitly prohibiting the use of certain fuels and technologies for energy production.

In addition to do's and don'ts, solutions that support the implementation of low-carbon technologies should be expanded (Adamczyk et al., 2017) The Clean Air program, launched in September 2018, aimed at reducing harmful gas and dust emissions to the air, has not yet led to a noticeable reduction in emissions. The Clean Air Program assumes the granting of 
subsidies and loans aimed at the organic emission of gases and dust to the air from existing single-family residential buildings or to avoid the emission of air pollution from newly built residential buildings (Adamczyk \& Dylewski, 2017). The budget of The Clean Air program is 103 billion zlotys. The implementation of the program is expected to last until 2029. Unfortunately, for The Clean Air program to achieve and lead to thermal modernization of about 3.5 million residential buildings, it would be necessary to sign three hundred and several dozen thousand contracts each year. However, during the first 10 months of operation of this program, about 30,000 applications were considered positively. Despite the considerable financial resources provided for limiting the emission of harmful substances into the air, the effectiveness of the solutions introduced in 2018 can be assessed only in a few years (Poór et al., 2015).

To effectively reduce gas and dust emissions to the air, various solutions should be implemented in parallel. Considering that in Poland, heating of single-family buildings has a large share in gas and dust emissions to the air, the possibilities of reducing pollution caused by burning fossil fuels in home boiler rooms should be analysed. For this purpose, the LCA technique is helpful, which indicates how to identify more environmentally friendly ways to generate energy needed for heating buildings (Zarębska \& Dzikuć, 2013; Barros et al., 2020).

LCA is a technique that allows comparing different types of boilers for heating apartments and indicate a solution that will burden the environment the least. The LCA assessment takes into account the entire life cycle of a product, from raw material extraction and processing, through product manufacturing, distribution, use, reuse, maintenance, recycling and final disposal, and transport. The International Organization for ISO Standardization defines LCA as a technique for assessing environmental aspects and potential impacts associated with a product (Burchart-Korol et al., 2018, Adamczyk \& Dzikuć, 2014).

The road transport sector has a significant, untapped potential for the development of a low-carbon economy (Tucki et al., 2019a; Bogacki and Bździuch, 2019). The growing number of cars in Poland significantly contributes to increasing greenhouse gas emissions. In Poland, cars that do not meet current environmental standards dominate, because they were often manufactured several years ago. The average age of a car registered in Poland is 13 years. It is necessary to look for solutions that reduce the number of old cars traveling on Polish roads. This can be achieved by supporting users when buying cars that will be less harmful to the environment and improve the functioning of public transport, which can contribute to giving up the frequent use of their own car.

\section{Conclusions}

The article indicates the aspects of low-carbon development and indicates some of the actions that can effectively reduce emissions to the air. It should be emphasized that the implementation of the indicated solutions will be easier with the growing social acceptance, which is the result of the need to live in a clean environment and the use of products that 
have been produced using low-carbon technologies. However, to increase social acceptance for implementing low-carbon solutions, educational activities will be necessary.

In order to ensure low-carbon development, it will be indispensable to implement solutions that will not be approved of by everyone, such as various orders and bans. An example of such a solution successfully used in many European cities is the introduction of a ban on entering city centers for cars that do not meet current ecological standards. It will also be necessary to enforce existing legal solutions more effectively. These activities must be carried out in a wide range. On the one hand, it is vital to give up several million old type boilers that are used to heat single-family buildings. These boilers can be replaced by more ecological solutions such as heat pumps, however, to be implemented on a large scale, financial support from the state is necessary.

It is urgent to accelerate the reduction of electricity generation in hard coal and lignite power plants. For this purpose, it is crucial to create to a greater extent more opportunities for renewable energy development. The growing energy needs of a developing country require new production capacity. Low-carbon solutions should be promoted, which due to, among others EU climate policy, may turn out to be much more economical in the next few years. Micro installations that can be located near almost every single-family building may prove to be particularly beneficial. The development of distributed energy will also reduce the need to transmit energy over long distances, which is necessary in the case of dominance of large coal power plants.

Acknowledgments: This study was conducted and financed in the framework of the research project "Economic aspects of low carbon development in the countries of the Visegrad Group", granted by the National Science Centre, Poland. Program OPUS, grant No. 2018/31/B/HS4/00485.

\section{References}

Adamczyk, J., \& Dylewski, R. (2017). Analysis of the sensitivity of the ecological effects for the investment based on the thermal insulation of the building: A Polish case study. Journal of Cleaner Production, 162, 856-864. https://doi.org/10.1016/j.jclepro.2017.06.123

Adamczyk, J., \& Dzikuć, M. (2014). The analysis of suppositions included in the Polish Energetic Policy using the LCA technique - Poland case study. Renewable and Sustainable Energy Reviews, 39, 42-50. https://doi.org/10.1016/j.rser.2014.07.083

Adamczyk, J., Piwowar, A., \& Dzikuć, M. (2017). Air protection programmes in Poland in the context of the low emission. Environmental Science and Pollution Research, 24(19), 16316-16327. https://doi.org/10.1007/s11356017-9233-9

Assessment of air quality in zones in Poland for 2017. (2018). Chief Inspectorate of Environmental Protection, Warszawa (in Polish).

Balmes, J. R. (2019). Household air pollution from domestic combustion of solid fuels and health. Journal of Allergy and Clinical Immunology, 143(6), 1979-1987. https://doi.org/10.1016/j.jaci.2019.04.016

Barros, M. V., Salvador, R., Piekarski, C. M., de Francisco, A. C., \& Freire, F. M. C. S. (2020). Life cycle assessment of electricity generation: a review of the characteristics of existing literature. The International Journal of Life Cycle Assessment, 25(1), 36-54. https://doi.org/10.1007/s11367-019-01652-4

Bedir, S., \& Yilmaz, V. M. (2016). $\mathrm{CO}_{2}$ emissions and human development in OECD countries: granger causality analysis with a panel data approach. Eurasian Economic Review, 6(1), 97-110. https://doi.org/10.1007/s40822015-0037-2

Bielaczyc, P., \& Woodburn, J. (2019). Trends in Automotive Emission Legislation: Impact on LD Engine Development, Fuels, Lubricants and Test Methods: a Global View, with a Focus on WLTP and RDE Regulations. Emission Control Science and Technology, 5, 86-98. https://doi.org/10.1007/s40825-019-0112-3 
Bitat, A. (2018). Environmental regulation and eco-innovation: the Porter hypothesis refined. Eurasian Business Review, 8(3), 299-321. https://doi.org/10.1007/s40821-017-0084-6

Bogacki, M., \& Bździuch, P. (2019). Predicting the spatial distribution of emissions from urban buses based on previously measured data and scenarios for their modernization in the future. Case study: Krakow, Poland. Atmospheric Environment, 199, 1-14. https://doi.org/10.1016/j.atmosenv.2018.11.009

Buoli, M., Grassi, S., Caldiroli, A., Carnevali, G. S., Iodice, F. S., Cantone, L., Pergoli, L., \& Bollat, V. (2018). Is there a link between air pollution and mental disorders? Environment International, 118, 154-168. https://doi.org/10.1016/j.envint.2018.05.044

Burchart-Korol, D., Pustejovska, P., Blau, A., Jursova S., \& Korol, J. (2018). Comparative life cycle assessment of current and future electricity generation systems in the Czech Republic and Poland. International Journal of Life Cycle Assessment, 23, 2165-2177. https://doi.org/10.1007/s11367-018-1450-z

Ciupek, B., Janeba-Bartoszewicz, E., \& Urbaniak, R. (2019). Effect of fineness and increased humidity of carbonaceous fuels on the chemical composition of exhaust gases. Przemyst Chemiczny, 98(8), 1283-1285. https://doi.org/10.15199/62.2019.8.15

Costantini, V., Crespi, F., \& Paglialunga, E. (2019). Capital-energy substitutability in manufacturing sectors: methodological and policy implications. Eurasian Business Review, 9(2), 157-182. https://doi.org/10.1007/s40821-018-0114-z

Cutz, L., Berndes, G., \& Johnsson, F. (2019). A techno-economic assessment of biomass co-firing in Czech Republic, France, Germany and Poland. Biofuels, Bioproducts and Biorefining, https://doi.org/10.1002/bbb.2034

Czyżewski, B., Trojanek, R. Dzikuć, M., \& Czyżewski, A. (2020). Cost effectiveness of the common agricultural policy and environmental policy in country districts: spatial spillovers of pollution, bio-uniformity and green schemes in Poland. Science of the Total Environment, 726, 138254. https://doi.org/10.1016/j.scitotenv.2020.138254

Dai, J., Kesternich, M., Löschel, A., \& Ziegler, A. (2015). Extreme weather experiences and climate change beliefs in China: An econometric analysis. Ecological Economics, 116, 310-321. https://doi.org/10.1016/j.ecolecon.2015.05.001

Dzikuć, M. (2013). Energy security of urban and rural Lubuskie Land = Bezpieczeństwo energetyczne miast i wsi województwa lubuskiego. Rynek Energii, 104(1), 56-61.

Dzikuć, M., Dzikuć, M., \& Łasiński, K. (2017). Technical and Economic Aspects of Low Emission Reduction in Poland. International Journal of Applied Mechanics and Engineering, 22(4), 1107-1112. https://doi.org/10.1515/ijame-2017-0072

Dzikuć, M., Dzikuć, M., \& Siničáková, M. (2017). The social aspects of low emission management in the Nowa Sól district. Management, 21(1), 237-249. https://doi.org/10.1515/manment-2015-0091

Dzikuć, M., Kuryło, P., Dudziak, R., Dzikuć, M., \& Godzisz, K. (2020). Selected Aspects of Combustion Optimization of Coal in Power Plants. Energies, 13(9), 2208. https://doi.org/10.3390/en13092208

European Environment Agency. (2020). Retrieved November 28, 2020, from https://www.eea.europa.eu.

European Environment Agency. (2020). European Union emission inventory report 1990-2018 under the UNECE Convention on Long-range Transboundary Air Pollution (LRTAP) (Report No 05/2020). Luxembourg: Publications Office of the European Union.

Garba, A., Tama, U. A., \& Ammani, A. I. (2020). Deforestation, sectoral $\mathrm{CO}_{2}$ emissions and climate change nexus: Fresh evidence from Nigeria. International Journal of Multidisciplinary Research and Growth Evaluation, 1, 16-27. http://www.allmultidisciplinaryjournal.com/archivesarticle/2020.v1.i3.38.pdf

Junga, R., Pospolita, J., Niemiec, P., Dudek, M., \& Szleper, R. (2020). Improvement of coal boiler's efficiency after application of liquid fuel additive. Applied Thermal Engineering, 179, 115663. https://doi.org/10.1016/j.applthermaleng.2020.115663

Kibria, G., Haroon, A. K. Y., \& Nugegoda, D. (2018). Low-carbon development (LCD) pathways in Australia, Bangladesh, China and India - a review. Journal of Climate Change, 4, 49-61. https://doi.org/10.3233/jcc-180006

Kopczyński, M., Lasek, J., Iluk, A., \& Zuwała, J. (2017). The co-combustion of hard coal with raw and torrefied biomasses (willow (Salix viminalis), olive oil residue and waste wood from furniture manufacturing). Energy, 140(1), 1316-1325. https://doi.org/10.1016/j.energy.2017.04.036

Laskowski, P., Zasina, D., Zimakowska-Laskowska, M., Zawadzki, J., \& Warchałowski, A. (2019). Vehicle Hydrocarbons' Emission Characteristics Determined Using the Monte Carlo Method. Environmental Modeling $\mathcal{E}$ Assessment, 24(3), 311-318. https://doi.org/10.1007/s10666-018-9640-4 
Leisen, R., Steffen, B., \& Weber, C. (2019). Regulatory risk and the resilience of new sustainable business models in the energy sector. Journal of Cleaner Production, 219(10), 865-878. https://doi.org/10.1016/j.jclepro.2019.01.330

Leseure, M., Robins, D., Wall, G., \& Jones, D. (2019). Making the most out of renewable energy opportunities: Lessons learned from a regional strategic mapping approach. International Journal of Energy Sector Management, 13(1), 212-228. https://doi.org/10.1108/IJESM-02-2017-0011

Mikielewicz, D., Kosowski, K., Tucki, K., Piwowarski, M., Stępień, R., Orynycz, O., \& Włodarski, W. (2019). Influence of Different Biofuels on the Efficiency of Gas Turbine Cycles for Prosumer and Distributed Energy Power Plants. Energies, 12(16), 3173. https://doi.org/10.3390/en12163173

Piwowar, A. (2019). Buildings in agricultural holdings in the context of low-carbon development of the agriculture and rural areas in Poland. In Education Excellence and Innovation Management through Vision 2020. 33rd IBIMA Conference Proceedings (pp. 322-331). https://ibima.org/accepted-paper/buildings-in-agricultural-holdings-inthe-context-of-low-carbon-development-of-the-agriculture-and-rural-areas-in-poland

Piwowar, A., \& Dzikuć, M. (2019). Development of renewable energy sources in the context of threats resulting from low-altitude emissions in rural areas in Poland: A review. Energies, 12(18), 3558. https://doi.org/10.3390/en12183558

Poór, P. Šimo, M., \& Karkov, M. (2015). CMMS as an effective solution for company maintenance costs reduction. In Production Management and Engineering Sciences (pp. 241-246).

Romanowska-Duda, Z., Piotrowski, K., Wolska, B., Dębowski, M., Zieliński, M., Dziugan, P., \& Szufa, S. (2020). Stimulating effect of ash from Sorghum on the growth of Lemnaceae A New Source of Energy Biomass. In: M. Wróbel., M. Jewiarz, \& A. Szlęk (Eds), Renewable Energy Sources: Engineering, Technology, Innovation, Springer Proceedings in Energy (pp. 341-349). Springer, Cham. https://doi.org/10.1007/978-3-030-13888-2_34

Sass, V., Kravitz-Wirtz, N., Karceski, S. M., Hajat, A., Crowder, K., \& Takeuchid, D. (2017). The effects of air pollution on individual psychological distress. Health $\mathcal{E}$ Place, 48, 72-79. https://doi.org/10.1016/j.healthplace.2017.09.006

Stewart, J., Anda, M., \& Harper, R. J. (2019). Low-carbon development in remote Indigenous communities: Applying a community-directed model to support endogenous assets and aspirations. Environmental Science E Policy, 95, 11-19. https://doi.org/10.1016/j.envsci.2019.01.003

Szatyłowicz, E., \& Skoczko, I. (2019). Evaluation of the PAH Content in Soot from Solid Fuels Combustion in Low Power Boilers. Energies, 12(22), 4254. https://doi.org/10.20944/preprints201910.0317.v1

Szufa, S., Dzikuć, M., Adrian, Ł., Piersa, P., Romanowska-Duda, Z., Lewandowska, W., Marczak, M., Błaszczuk, A., \& Piwowar, A. (2020a). Torrefaction of oat straw to use as solid biofuel, an additive to organic fertilizersfor agriculture purposes and activated carbon-TGA analysis, kinetics. E3S Web of Conferences, 154, 02004. https://doi.org/10.1051/e3sconf/202015402004

Szufa, S., Wielgosiński, G., Piersa, P., Czerwińska, J., Dzikuć, M., Adrian, Ł., Lewandowska, W., \& Marczak, M., (2020b). Torrefaction of Straw from Oats and Maize for Use as a Fuel and Additive to Organic Fertilizers TGA Analysis, Kinetics as Products for Agricultural Purposes. Energies, 13(8), 2064. https://doi.org/10.3390/en13082064

Truong, A. H., Patrizio, P., Leduc, S., Kraxner, F., \& Ha-Duong, M. (2019). Reducing emissions of the fast growing Vietnamese coal sector: The chances offered by biomass co-firing. Journal of Cleaner Production, 215, 13011311. https://doi.org/10.1016/j.jclepro.2019.01.065

Tucki, K., Mruk, R., Orynycz, O., Wasiak, A., Botwińska, K., \& Gola, A. (2019a) Simulation of the Operation of a Spark Ignition Engine Fueled with Various Biofuels and Its Contribution to Technology Management. Sustainability, 11(10), 2799. https://doi.org/10.3390/su11102799

Tucki, K., Orynycz, O., Wasiak, A., Świć, A., \& Dybaś, W. (2019b). Capacity Market Implementation in Poland: Analysis of a Survey on Consequences for the Electricity Market and for Energy Management. Energies,12(5), 839. https://doi.org/10.3390/en12050839

Wattanakuljarus, A. (2019). Effects and burdens of a carbon tax scheme in Thailand. Eurasian Economic Review, 9(2), 173-219. https://doi.org/10.1007/s40822-018-0100-x

World Health Organization. (2020). European detailed mortality database. Regional Office for Europe, Copenhagen. Retrieved November 13, 2020, from https://www.who.int/healthinfo/statistics/mortality_rawdata/en

Woźniak, J., \& Pactwa K. (2018). Responsible Mining-The Impact of the Mining Industry in Poland on the Quality of Atmospheric Air. Sustainability, 10(4), 1184-1200. https://doi.org/10.3390/su10041184

Yang, T., \& Liu, W. (2018). Does air pollution affect public health and health inequality? Empirical evidence from China. Journal of Cleaner Production, 203(1), 43-52. https://doi.org/10.1016/j.jclepro.2018.08.242 
Zaporozhets, A. O., \& Khaidurov, V. V. (2020). Mathematical Models of Inverse Problems for Finding the Main Characteristics of Air Pollution Sources. Water, Air, and Soil Pollution, 231, 563. https://doi.org/10.1007/s11270020-04933-z

Zarębska, J, \& Dzikuć, M. (2013). Determining the environmental benefits of life cycle assessment (LCA) on example of the power industry. Scientific Journals Maritime University of Szczecin, 34(163), 97-102. 